mediate and advanced, and as a consequence is unsuitable in treatment for all but a few undergraduate and graduate students. Thero is too much emphasis on research for undergraduates to buy the book, which is too broad to be of real use to the graduate student and researcher. Even tho detailed treatments such as preferred orientation, and microscopy involving X-ray and electron diffraction, are of limited value because the researcher invariably consults the more detailcd up to date work of, for example, the A.S.M. book on Recrystallization, Grain Growth and Textures and Electron Microscopy of T'hin Crystals, respectively. Thus although such a book as Structure of Metals was invaluable up to the early sixties, its usefulness today is much more limited. Novertheless, a tremendous amount if work has been put into the present edition and no doubt the book will still be useful as a quick reference to a wide variety of topics, without being the classic of the oarlier years.

R. E. SMaliman

\section{FLAME PHOTOMETRY}

\section{Flame Photometry Theory}

By E. Pungor. 'Translation edited by R. A. Chalmers. (The Van Nostrand Series in Analytical Chemistry.) Pp. $x+200$. (London: D. Van Nostrand Company, Ltd. ; Princeton, N.J. : D. Van Nostrand Company, Inc., 1967.) 60s.

THIs is a very worthwhile book, collecting together a wealth of scattered information on flame processes in the broadest sense of the term. Flame photometry is now a widoly used analytical tool; the ease and rapidity with which it produces data engender a temptation to relegate the underlying principles to a subsidiary role. There are few areas in analytical chemistry where the relationship between theory and practice is as tenuous as it is in emission spectrography. The book is written primarily for analysts and it will certainly be welcomed by them. It serves to underline the fact that the apparently simple and rugged technique of flame photometry is based on complex interrelationships of chemical and thermal processes. It can be recommended to a wider readership as an informative text.

Considerably more than half of the book is devoted to two important chapters. 'The first is a survey of flame processes, covering the basic parameters for evaluating flame performance together with the experimental techniques involved. The various theories of flame propagation are also discussed. The second chapter is concerned with radical equilibria in flames and again a substantial amount of experimental information is given. The treatment is largely concerned with hydrogen/oxygen flames, but the literature on hydrocarbon flames is adequately covered. The remainder of the book is made up of brief chapters on flame temperature and its measurement, important flames used in flame photometry, theory of atomization and spray collection (based largely on the author's own work) and flame emission and atomic absorption spectroscopy. It is well produced and reasonably priced.

J. K. Foreman

\section{AUSTRALIAN LANDFORMS}

Landform Studies from Australia and New Guinea Edited by J. N. Jennings and J. A. Mabbutt. Pp. xxiii + 434. (London : Cambridge University Prcss, 1967.) $1058 . ; \$ 19.50$.

THIs is a very Australian book. It is a collection of essays dealing with landforms in Australia and Now Guinea. The three essays concerned with New Guinea are almost exclusively confined to the highlands. The other fourteen essays cover many characteristic aspects of Australian landform study, and although the book is not intended to be a regional geomorphology almost every principal region is represented. It is tho Australian-ness that gives the main unifying theme to the book because tho essays are of very different types and many aspects of landform study are insluded. 'Therefore, although the reader is dealing with seventicen different authors and their different approaches, the collection is remarkably successful. Most of the essays are between about 10,000 and 16,000 words long, one or two are longer, and the shortest is an interest. ing little essay by B. P. Ruxton on "Slopewash under Mature Primary Rainforest in Northern Papua".

The studies are very variable, in that some contain results of new research, while others are more like review articles. Moreover, the whole range of disciplines concerned with landform study is dealt with. Modern statistical and computer techniques have been used by J. G. Speight in "Spectral Aralysis of Meanders of some Australasian Rivers", and by D. S. Simonett in his discussion of landslide distribution and its relationship to earthquakes in the Bewani and Torricelli mountains in New Guinea. More conventional field geomorphology is represented by C. R. Twidale's work on the "Hillslopes and Pediments on the Flinders Ranges" and by $\mathbf{R}$. W. Galloway's discussion of the pre-, sub- and post-basalt surfaces of tho Huntor valley in New South Wales. Edmund Gill uses the methods of the Quaternary geologist to unravel the problems of the evolution of the coast. line between Warnambool and Port Fairy in western Victoria.

To make any really constructive criticism of the evidence and the conclusions presented in these essays, one would need to know Australia extremely woll and to have been working most recently in the areas conccrned. Although I am familiar with cortain parts of Australia, it is only possible to make general commonts on them. As would be expected from the remarks already made, the most interesting and perhaps the most successful essays are those dealing essentially with Australian rather than with more general problems. These include particularly the studies of the geomorphological history of the Lake Eyre basin by $H$.' Wopfner and C. R. 'Twidale, those dealing with landforms and laterites in both north and south-western Australia (by J. Hays and by M. J. Muleahy), and that discussing soil poriodicity in relation to landform development in south-eastern Australia by B. Butlor. It may be that these studies evoke more especially the nostalgia that affects all who have lived in Australia, which is referred to by Professor Hills in his foreword.

But it does seem to me that, in the essays where there is a considerable amount of European literature (and Amorican) available, the collection is rather less successful. It secms to indicate that the study of landforms in Australia has had to rid itself of goomorphological ideas inherited from other continents before it could really progress. This is illustrated by the development of ideas on the glaciation and peri-glaciation in Tasmania, which is the subject of a beautifully clear and succinct contribution by J. L. Davies. 'The survival of outmoded concepts is also indicated at the end of J. Mabbutt's interesting work on the "Denudation Chronology in Central Australia", in the comment on the "usefulness of the concept of the arid cycle" (page 179); this scerns to a European as unnecessary, as the concept of the arid cycle left us long ago. Survival is also faintly perceptible in my colleague J. N. Jennings's persistence in discussing the karst areas of Australia in purely morpho-climatic terms, at a stage when there is a great omphasis, in eastern Europe at any rate, on lithological studies in limestone terrains. Nevertheless, it is very good to see the work of the Australian speleologists progressing so well and so much work being done in the Australian karst areas.

The two final essays are more in the nature of reviews. The first attempts to discuss the factors responsible 